\title{
Wingless/Wnt Signaling in Intestinal Development, Homeostasis, Regeneration and Tumorigenesis: A Drosophila Perspective
}

\author{
Ai Tian, Hassina Benchabane and Yashi Ahmed* \\ Department of Molecular and Systems Biology and the Norris Cotton Cancer Center, \\ Geisel School of Medicine at Dartmouth College, Hanover, NH 03755, USA; ai.tian@dartmouth.edu (A.T.); \\ hassina.benchabane@dartmouth.edu (H.B.) \\ * Correspondence: yfa@dartmouth.edu; Tel.: +1-603-650-1027
}

Received: 30 January 2018; Accepted: 24 March 2018; Published: 28 March 2018

\begin{abstract}
In mammals, the Wnt/ $\beta$-catenin signal transduction pathway regulates intestinal stem cell maintenance and proliferation, whereas Wnt pathway hyperactivation, resulting primarily from the inactivation of the tumor suppressor Adenomatous polyposis coli (APC), triggers the development of the vast majority of colorectal cancers. The Drosophila adult gut has recently emerged as a powerful model to elucidate the mechanisms by which Wingless/Wnt signaling regulates intestinal development, homeostasis, regeneration, and tumorigenesis. Herein, we review recent insights on the roles of Wnt signaling in Drosophila intestinal physiology and pathology.
\end{abstract}

Keywords: Wnt/Wingless signaling; Drosophila gut; animal model; intestinal physiology and pathology; Adenomatous polyposis coli (APC); colorectal cancer

\section{The Canonical Wnt/ $\beta$-Catenin Signaling Pathway}

\subsection{Wnt/B-Catenin Signaling Pathway}

The canonical Wnt signaling pathway regulates the cytoplasmic level of the transcriptional coactivator $\beta$-catenin [1-3]. In the absence of Wnt ligand stimulation, cytoplasmic $\beta$-catenin is targeted for proteolysis by a "destruction complex", which includes the two tumor suppressors Axin and Adenomatous polyposis coli (APC), and two kinases, glycogen synthase kinase 3 (GSK3) and casein kinase $1 \alpha(\mathrm{CK} 1 \alpha)$. The destruction complex promotes $\beta$-catenin phosphorylation, ubiquitination, and proteasomal degradation, thereby preventing the transcriptional regulation of Wnt target genes [4]. Binding of Wnt ligands to their co-receptors Frizzled (Fz) and low-density lipoprotein receptor-related protein 5/6 (LRP5/6; herein LRP6) activates signaling [5-7]. A consequent cascade of events assembles the "signalosome", including the formation of a Fz-LRP6 complex, recruitment of Dishevelled (Dvl) to this complex, phosphorylation of the cytoplasmic tail of LRP6, and its association with Axin and GSK3 [8]. These events either result in the disassembly of the destruction complex, or in an alternative model, inhibit $\beta$-catenin ubiquitination within an intact complex $[1,3,9,10]$. In both of the models, $\beta$-catenin accumulates in the cytoplasm and translocates to the nucleus, resulting in its association with TCF and other transcriptional coactivators to regulate Wnt target gene expression [11-13].

\subsection{Wnt/B-Catenin Signaling in Development and Disease}

Wnt/ $\beta$-catenin signaling regulates many cell behaviors in metazoans $[2,14]$, including axis formation during development [15,16], maintenance of stem cell-replenished organs during adulthood [17-19], and faithful pattern restoration during tissue regeneration $[17,20,21]$. 
Because of the key roles of the Wnt pathway during development and homeostasis, its deregulation is associated with numerous congenital diseases, metabolic disorders, and cancers [2,22-24]. Notably, hyperactivation of Wnt signaling drives both the onset and the continued proliferation of colorectal cancer, which is among the leading causes of cancer-related death worldwide [18,25-28]. This underlies the intense effort to understand the roles of Wnt signaling in both intestinal physiology and pathology.

\section{Wnt/ $\beta$-Catenin Signaling in Mammalian Intestinal Physiology and Pathology}

A single layer of epithelial cells lines the lumen of the mammalian small intestine and colon, forming invaginations, termed crypts. The small intestinal epithelium also contains fingerlike protrusions termed villi. A massive renewal process, which is driven by intestinal stem cells (ISCs), replenishes the loss of differentiated intestinal epithelial cells [29]. Located at the crypt base, ISCs self-renew and give rise to transit-amplifying (TA) cells; the latter proliferate rapidly, migrate upwards, and differentiate into mature cells in the villi, where digestion and absorption are fulfilled $[18,25,26]$. Wnt pathway activity is graded at this site, with the highest levels at the base of the crypt [30-33]. Inhibition of Wnt signaling results in both abrupt cessation of proliferation and loss of ISCs, consequently leading to ablation of the intestinal epithelium [34-39]. Conversely, potentiation of Wnt signaling increases ISC number [40,41]. Together, these lines of evidence reveal the crucial roles of Wnt signaling in ISC self-renewal and proliferation during homeostasis.

The aberrant activation of the Wnt pathway in ISCs promotes adenoma formation. Mutations in $A P C$ trigger this tumor-initiating step, underlying both the hereditary cancer syndrome, termed familial adenomatous polyposis (FAP) and the majority of sporadic cases (approximately 85\%) of colorectal cancer [42-46]. Mutations affecting other components of the Wnt pathway substitute for APC mutations in most other colorectal cancer cases [42,46-55]. The subsequent acquisition of additional mutations in other pathways facilitates the progression of these adenomas to malignancy [56-60]. Notably, the restoration of APC in APC-deficient colorectal tumors triggers cell differentiation and re-establishes intestinal homeostasis [61]; thus, even late-stage tumors continue to rely on hyperactivated Wnt signaling to sustain their growth. This crucial requirement of Wnt pathway hyperactivation for both the initiation and the ongoing proliferation of colon cancer cells provides a potentially powerful target for therapeutic intervention. In recent years, several promising agents, including antibodies, small molecule inhibitors, and tailored peptides that interfere with Wnt pathway activation have been developed $[2,53,62-67]$. In particular, small molecule inhibitors of the ADP-ribose polymerase Tankyrase stabilize Axin and inhibit Wnt signaling in APC-deficient tumor cells and Apc mutant mice [68-73]. These observations highlight the great potential of drugging the Wnt pathway for treatment of colorectal cancers. However, as the Wnt pathway is required both in colon cancers and in normal stem cells, challenges remain in concomitantly achieving efficacy and safety [2,23,62,74]. A better understanding of the mechanistic differences that exist between physiological levels of Wnt signaling in the normal intestinal homeostasis versus the aberrantly increased levels found in pathologic states may provide selectivity between tumor and normal tissues, and is thus critical.

\section{The Drosophila Adult Gut: A Powerful Model for Studying Wnt Signaling}

Akin to the functional segmentation of the mammalian gastrointestinal tract [75-80], the Drosophila gut is subdivided into foregut, midgut, and hindgut, based on their distinct developmental origin and function. The midgut is further partitioned into compartments, termed the anterior, middle, and posterior midgut, with distinct digestive and metabolic functions, enterocyte architecture, gene expression profiles, and tumor susceptibility (Figure 1) [75,81-86]. Similar to that in its mammalian counterpart, Drosophila gut compartmentalization facilitates the sequential digestion of food and absorption of nutrients, as well as defense against infection. Resembling the mammalian digestive tract, the Drosophila adult midgut is comprised of a monolayer epithelium that is replenished regularly by ISCs $[85,87,88]$. ISCs give rise to either enteroblasts (EB) or 
pre-enteroendocrine cells (pre-EE), which subsequently differentiate into absorptive enterocytes (EC) or secretory enteroendocrine cells (EE), respectively [85,87-91].

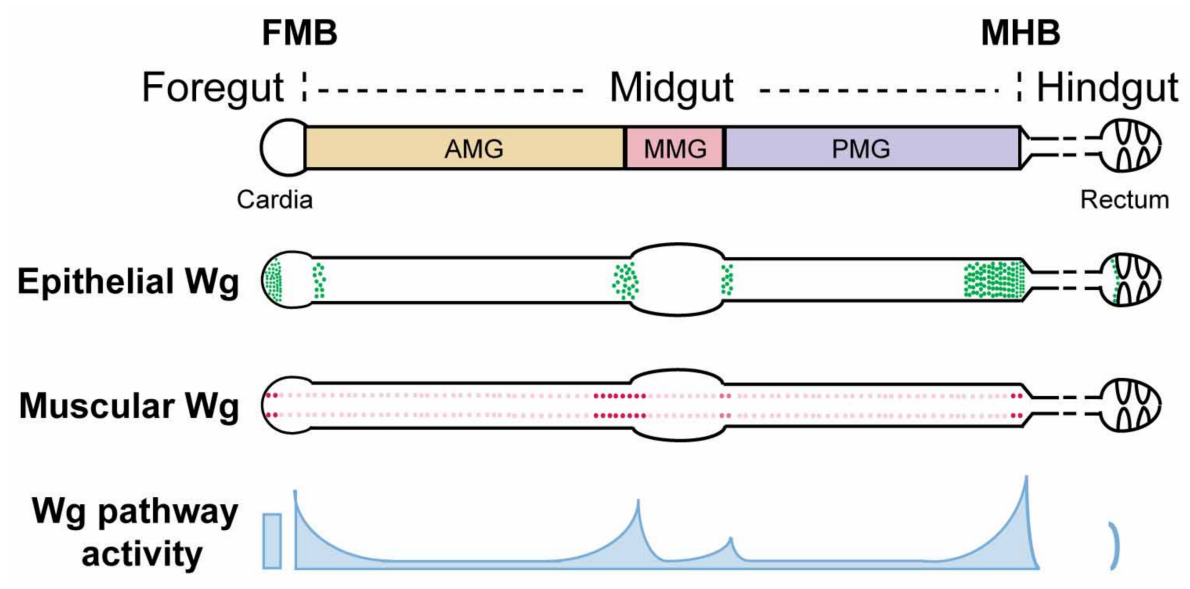

Figure 1. Schematic view of $w g$ expression and $\mathrm{Wg}$ pathway activation in the Drosophila adult gut. The Drosophila adult gut is divided into foregut, midgut, and hindgut. The foregut/midgut boundary (FMB) and midgut/hindgut boundary (MHB) provide local niches for region-specific stem cells and contain critical valves that regulate food entry and exit. The midgut is further partitioned into anterior midgut (AMG), middle midgut (MMG), and posterior midgut (PMG), based on major constrictions and the existence of a specific acid-secreting region in the MMG. A wg-gal4 knock-in line driving UAS-lacZ reveals wg expression in both the epithelium and the surrounding visceral muscle. At major compartment boundaries of the midgut, epithelial sources of $w g$ are detected within enterocytes. In addition, four rows of $w g$-expressing cells are detected in the surrounding circular visceral muscles throughout the entire length of the midgut. Instead of being uniform, these muscle sources of $w g$ are enriched at major compartment boundaries. Similarly, Wg pathway activation exists in gradients, exhibiting high-level expression at compartment boundaries and low-level expression throughout compartments.

Drosophila and mammalian guts share not only similar morphology, but also a requirement for Wnt signaling. One key difference is the reduced functional redundancy present in Wnt pathway components in Drosophila, providing a key advantage for elucidating their in vivo roles [15,92-94]. Furthermore, the ability to mark and manipulate stem cell lineages, to abrogate or to overactivate $\mathrm{Wg}$ signaling at defined time points, to study epithelial regeneration following injury, and to examine intestinal epithelial cell division, differentiation, and niche-stem cell contacts at the single cell level all add to the advantages of using Drosophila to study Wnt-driven physiology and pathology [91,95-99]. Moreover, the Drosophila gut also provides a powerful physiological context to test both novel Wnt pathway components and novel therapeutic agents that target the pathway [100-103].

\section{Wg Signaling in the Drosophila Gut: Development, Homeostasis, Regeneration, and Tumorigenesis}

\subsection{Wg Is Expressed at Major Compartmental Boundaries in the Adult Midgut}

The wg mRNA expression pattern in the adult gut has been determined using both in situ hybridization [104] and transcriptional reporters, including wg-lacZ (insertions of lacZ in the endogenous wg locus) [104-108], wg-gal4 [109,110], wg $\{K O$, cherry\} (cherry knock-in at the endogenous wg locus) [106,111], and $w g(K O$, gal4\} (gal4 knock-in at the endogenous wg locus) [106,111,112]. These combined efforts revealed that $\mathrm{Wg}$ originates from both the gut epithelium and the visceral muscle. First, the level of $w g$ expression in visceral muscles that surround the gut epithelium peaks at major intestinal compartment boundaries, including the foregut/midgut boundary (FMB), 
anterior/middle midgut boundary, middle/posterior midgut boundary, and midgut/hindgut boundary (MHB) [104,106] (Figure 1). Overexpression of wg in visceral muscle induces Wg target gene expression in the gut epithelium, suggesting that $\mathrm{Wg}$ derived from intestinal muscle communicates with the juxtaposed gut epithelium and instructs its behavior [106]. Second, wg is also expressed in the intestinal epithelium at major compartment boundaries including the FMB, anterior/middle midgut border, middle/ posterior midgut border, MHB, and ileum/rectum border [106,107,109,110,112] (Figure 1). Specifically within midgut, wg expression is detected in enterocytes. Approximately 16 contiguous rows of cells in the adult terminal posterior midgut express $w g$, which is a significantly longer range than that present in the third instar larval wing imaginal disc. Whether there exist epithelial sources of $\mathrm{Wg}$ ligands inside the compartments (away from the boundaries) awaits further investigation. In summary, wg mRNA expression is enriched at compartment boundaries in both the gut epithelium and its overlying visceral muscle.

Studies with a monoclonal Wg antibody confirmed some of the expression pattern that was revealed by $w g$ transcriptional reporters and in situ hybridization [104,110,112-114]. Wg protein is present in visceral muscles and is reduced upon RNAi-mediated knock down of $w g$ specifically in muscle $[104,113]$. Furthermore, secreted Wg protein associates with progenitor cells within compartments during homeostasis, $[104,112,113]$, and Wg protein levels are greatly increased during regeneration following injury [113] or upon the overexpression of the Ret receptor tyrosine kinase [112]. In addition, epithelial $\mathrm{Wg}$ protein is also detected at the MHB $[110,114]$. The presence of $\mathrm{Wg}$ protein at other intestinal compartment boundaries, and the source of the progenitor cell-associated $\mathrm{Wg}$ protein await further investigation, requiring reagents that permit an increased sensitivity in $\mathrm{Wg}$ protein detection.

The Drosophila genome encodes seven Wnt genes [115]. In addition to $\mathrm{Wg}$, the other six Wnts (Wnt2, Wnt4, Wnt5, Wnt6, Wnt10, and WntD) are also expressed in the Drosophila intestine (FlyGut-seq [98]; Figure 2). Their precise expression pattern and contribution to the intestinal physiology awaits further work.

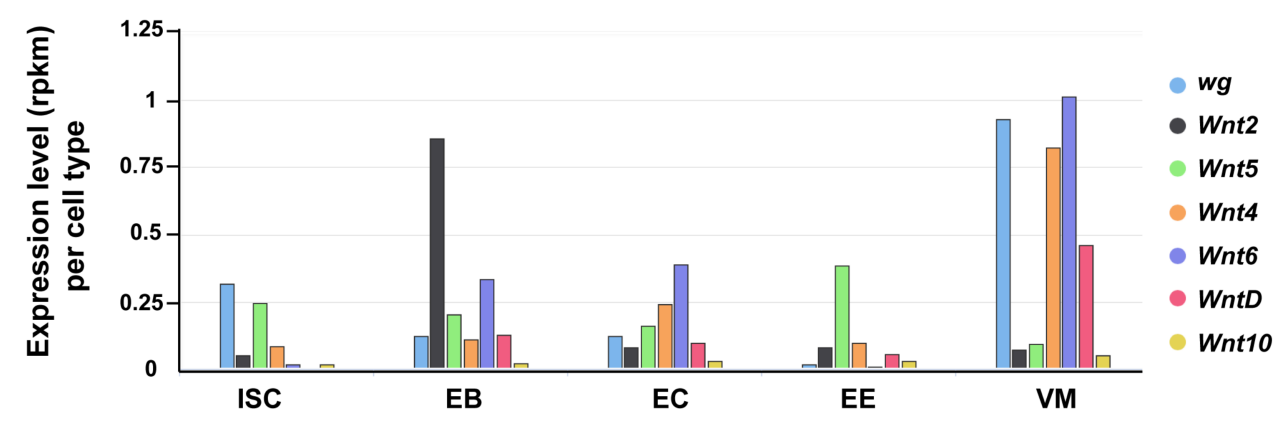

Figure 2. Expression of Drosophila Wnts in the gut. The seven Drosophila Wnt genes exhibit differential expression levels across distinct gut cell types (FlyGut-seq). ISC (intestinal stem cell); EB (enteroblast); EC (enterocyte); EE (enteroendocrine cell); and, VM (visceral muscle).

\subsection{Graded Activation of Wg Signaling at Major Compartment Boundaries in the Drosophila Midgut}

The distinct regions in the Drosophila adult intestine at which Wg signaling is active have been identified by the analysis of Wg pathway target genes [81,95,106]. frizzled $3(f z 3)$ and naked cuticle $(n k d)$ are target genes that are activated directly by Armadillo/ $\beta$-catenin-TCF in several physiological contexts and are feedback antagonists of the Wg pathway [116-118]. Fz3-RFP, which is a $2.3 \mathrm{~kb}$ promoter fusion line [119], and $n k d-l a c Z$, an insertion of lacZ in the endogenous $n k d$ locus [118], respond to both loss and gain of $\mathrm{Wg}$ signaling in distinct developmental contexts [118-123]. The specificity of these two target gene reporters in the intestine has been verified by mutant clonal analysis of essential Wg pathway components [101,106]. In the adult gut epithelium, fz3-RFP and nkd-lacZ exhibit overlapping graded expression patterns, peaking at major compartment boundaries and decreasing as 
a function of distance from the boundaries [81,101,106,107]. Asymmetric gradients of Wingless target genes are present at the AMG/MMG boundary and the MHB boundary [81,106]. In addition, low-level expression of $\mathrm{Wg}$ target genes is also present within the interior of compartments $[81,101,106]$. Thus, Wg pathway activation peaks at the boundaries between intestinal compartments, decreases with distance from the boundaries, and is the lowest in the interior of compartments.

Loss-of-function clonal analysis of essential $\mathrm{Wg}$ pathway components also revealed that $\mathrm{Wg}$ stimulation activates $f z 3-R F P$ and $n k d-l a c Z$ expression specifically in ECs, both at the intestinal compartment boundaries and within the interior of compartments [106]. Wg-dependent activation of $f z 3-R F P$ expression also occurs in progenitor cells, but only those in the posterior terminal midgut $[106,107]$. Thus, under physiological conditions, $\mathrm{Wg}$ signaling is transduced within enterocytes along the entire midgut, and also in progenitor cells in the posterior terminal midgut. By contrast, in Apc1 Apc2 double null mutant clones, $f z 3-R F P$ expression is greatly induced in all intestinal cell types, including progenitor cells, EEs, and ECs [106]. Thus, all of the gut epithelial cells have the capacity to activate $\mathrm{Wg}$ signaling. The mechanism that restricts $\mathrm{Wg}$ pathway activation to a subset of intestinal epithelial cells under physiological conditions awaits further investigation, and may require improvement in the sensitivity of detection of destruction complex components in the Drosophila gut.

\subsection{Wg Directs Pattern Formation during Drosophila Gut Development}

The major regions of the Drosophila intestine are derived from distinct germ layers: the midgut arises from endoderm, whereas both the foregut and hindgut arise from ectoderm [124,125]. The midgut epithelium is generated from adult midgut precursors (AMPs) that are initially specified during embryogenesis [126,127]. During larval stages, AMPs undergo proliferation in clustered islets and are encapsulated by their own differentiated daughters, termed peripheral cells (PCs) [126-130]. At the onset of metamorphosis, the larval midgut epithelium degenerates, leaving intact only regions that are near the foregut/midgut and midgut/hindgut borders [107,110,114,127,131,132]. The PCs, which serve as a transient niche that prevents AMP differentiation in the larval gut, degenerate at this stage. The released AMPs undergo rapid proliferation, differentiation and dispersal, and the resulting gut primordia merge and elongate to rebuild the adult midgut epithelium. During this process, the vast majority of AMPs differentiate into ECs or EEs, whereas small subsets become the future adult ISCs [127-130,133-136]. Concomitantly, the surrounding visceral muscles contract and remodel, undergoing dedifferentiation and redifferentiation $[137,138]$. In contrast to the midgut, the developmental processes that rebuild the adult foregut and hindgut remain under debate. In one model, progenitors proliferate in defined zones at the foregut/midgut and midgut/hindgut borders, differentiate and extend cephalically or caudally during metamorphosis to replace the larval epithelium, and thereby give rise to the adult foregut and hindgut [110]. In an alternative model for hindgut development, the adult pylorus, ileum, and rectum are derived from independent larval precursors [114].

The complex developmental processes that direct formation of the Drosophila gut require precise spatiotemporal orchestration. How is this achieved? Whether Wnt/Wg signaling provides instructive signals for the development of distinct gut compartments, and the boundaries that separate them has been recently investigated. These studies shed light on three zones that are enriched for Wg pathway activation: the two distal boundaries that separate midgut from foregut and hindgut, and the copper cell region in the middle midgut.

\subsubsection{Wg Signaling in Formation of the Adult Intestinal Midgut/Hindgut Boundary during Pupation}

The midgut/hindgut boundary (MHB) partitions the endoderm-derived posterior terminal midgut from the ectoderm-derived anterior hindgut. Due to their distinct developmental origins, midgut and hindgut cells at this boundary exhibit distinct characteristics with respect to cell size, nuclear size, cell adhesion proteins, proliferation rate, presence of cuticle versus microvilli-rich brush border, and the overlying visceral muscle $[106,107,110,114,132]$. Juxtaposed posteriorly with the 
$\mathrm{MHB}$, the anteriormost adult hindgut cells, also termed the hindgut proliferation zone (HPZ), are formed by expansion of the hindgut progenitor cells during pupation [110]. The precise mechanism underlying the formation of the posterior terminal midgut, which lies immediately anterior to the $\mathrm{MHB}$, remains uncertain. In one model, the posterior terminal midgut is formed by bidirectional movement of neighboring cell populations and their subsequent adoption of new cell fates during metamorphosis [132]. Specifically, the anteriormost larval hindgut cells cross the MHB, lose their hindgut identity and subsequently transdifferentiate into posterior terminal midgut enterocytes. Concurrently, AMPs that are located immediately anterior to the posterior terminal midgut migrate posteriorly and give rise to the posterior terminal midgut progenitor cells and EEs [132]. In an alternative model, rather than undergoing transdifferentiation, a hybrid progenitor cell acts early in larval development to produce the posterior terminal midgut, MHB and pylorus [107].

Remarkably, Wg is secreted from three distinct sources at the MHB: epithelial cells in the posterior terminal midgut, a ring of epithelial cells at the anteriormost hindgut, and muscle fibers overlying the posterior terminal midgut $[106,107,110,114,132]$ (Figure 1). Together, these three sources contribute to the high levels of secreted $\mathrm{Wg}$ that induce high level $\mathrm{Wg}$ pathway activation around the MHB $[81,106,107]$, which is crucial for the proper development of this region in at least three distinct aspects. First, the level of $\mathrm{Wg}$ activity specifies the size of the anteriormost hindgut region (HPZ); Wg pathway hyperactivation induces HPZ expansion, whereas Wg signaling inhibition leads to adult hindgut loss [110]. Similarly, Wg pathway activation also determines the size of the posterior terminal midgut as $\mathrm{Wg}$ overexpression results in an abnormally enlarged posterior terminal midgut [132]. Whether this defect results from an aberrantly increased number of hindgut progenitor cells that migrate anteriorly or from an expanded proportion of the hybrid progenitor population that adopts terminal midgut cell fate remains unclear. Third, Wg signaling provides positional cues for cells to adopt proper cell fate in the reformation of the MHB region during pupation and to prevent lineage mixing, the inhibition of which leads to two additional phenotypes [106]. In the first phenotypic class, $\mathrm{Wg}$ signaling-defective cells in the posterior terminal midgut fail to adopt a midgut fate and exhibit characteristics of hindgut epithelia (small nuclear and cell size, and expression of hindgut-specific markers) and are "tightly-packed" in a spiral pattern. Consequently, they segregate from the neighboring wild-type midgut epithelium as discrete domains. It is thus possible that $\mathrm{Wg}$ signaling instructs the transdifferentiation of hindgut cells to midgut cells following their migration into the midgut, or alternatively, graded $\mathrm{Wg}$ pathway activation might be required to specify individual cell fates within the population of hybrid progenitors during metamorphosis. In the second phenotypic class, Wg signaling-defective posterior terminal midgut cells display abnormally large nuclear and cell size. These cells most likely derive from posteriorly-migrating AMPs that fail to adopt posterior terminal midgut cell fate following their migration. Furthermore, in contrast to their normal restriction within the posterior terminal midgut, some of these abnormally large cells invade the hindgut. Together, these recent observations suggest that Wg signaling is critical for cell sorting, patterning, and lineage separation during the reformation of the MHB during metamorphosis.

4.3.2. Wg Signaling in Formation of the Foregut/Midgut Boundary of the Adult Gut during Development

High levels of Wg protein and Wg pathway activity are present not only at the MHB, but also at the foregut/midgut boundary (FMB) [106,109]. Disruption of Wingless signaling during development gives rise to cells of abnormal size and alignment at this boundary, distorting the normal structure of the cardia [106]. Thus, as is the case for the MHB, Wg signaling also instructs the proper cell fate specification at the FMB during development.

\subsubsection{Wg Signaling in Embryonic and Larval Gut Development}

Wg signaling is also required during embryonic and larval gut development. During embryogenesis, Wg signaling directs left-right asymmetry of the foregut and the anterior midgut, 
disruption of which results in left-right inversion or loss of laterality [139]. In addition, Wg-dependent patterning is essential for the development of the embryonic hindgut and rectum [140]. In the larval midgut, high levels of $\mathrm{Wg}$ and $\mathrm{Wg}$ pathway activation are present at the boundaries of the middle midgut region $[106,141]$, which contains two distinct cell populations: the anterior acid-secreting "copper cells" and the posterior "large flat cells". Nearly all of the presumptive middle midgut cells have the intrinsic capacity to adopt either cell fate during development [141]. Two different thresholds of $\mathrm{Wg}$ concentration specify their fates: low levels of $\mathrm{Wg}$ promote copper cell fate, whereas high levels of Wg repress copper cell fate and promote the large flat cell fate [141]. Whether Wg signaling plays a similar role during the development of the adult middle midgut awaits further investigation. In summary, $\mathrm{Wg}$ is crucial to instruct proper patterning of the gut throughout development.

\subsection{Wg Signaling Regulates ISC Self-Renewal/Maintenance and Proliferation in the Drosophila Adult Gut during Homeostasis}

When nutrients are plentiful, the intestinal epithelium is replenished in a highly regulated process. Several findings support a role for Wg signaling in ISC self-renewal/maintenance. In distinct compartments along the anterior-posterior axis of the Drosophila gut, dominant negative TCF results in rapid loss of ISC lineages in the posterior midgut [104,113,142], the CCR ([143], and the cardia [109]. In the posterior midgut, $f z f z 2$ double mutant cells, as well as arm, or $d s h$ mutant cells are lost over time [104]. In addition, ISC number is reduced by the temperature sensitive wg mutant allele $\left(w g^{t s}\right)[104]$ and increased upon Wg overexpression $[104,109,144]$. However, controversy remains regarding the requirement for Wg signaling in ISC self-renewal, as: (1) ISC self-renewal is not affected upon concomitant inactivation of $A p c 1$ and $A p c 2$ in the posterior midgut [142]; (2) concomitant knockdown of $w g$ from epithelial and muscle sources or in $w g{ }^{C X 4}$ heterozygous mutants does not lead to significant loss of posterior midgut ISCs even after 30 days [113]; and, (3) in contrast with the effects of dominant negative TCF overexpression, inactivation of core Wnt pathway components with null alleles results only in mild effects on ISC maintenance during homeostasis [104]. Thus, dominant negative TCF may cause non-specific effects that muddle the role of Wg signaling in ISC self-renewal. In addition, contradictory observations have also left the role of Wingless signaling on ISC proliferation uncertain $[104,113]$.

More recently, several studies have demonstrated that Wg signaling is critical for intestinal homeostasis, but active primarily in enterocytes rather than in ISCs $[81,101,106]$. Wg signaling in enterocytes non-autonomously regulates JAK-STAT signaling in neighboring ISCs, thereby preventing ISC overproliferation during homeostasis. Together, these recent studies reveal that $\mathrm{Wg}$ signaling is essential to prevent aberrant increases in ISC proliferation during homeostasis.

\subsection{Wg Signaling in Adult Midgut and Hindgut Regeneration Following Injury}

During adulthood, the Drosophila intestinal epithelium may be exposed to damage from bacterial infection, chemical toxins, or mechanical stress. To repair the resultant injury, mechanisms have evolved to regenerate the damaged intestinal epithelium. Intestinal cells sense damage, induce compensatory ISC proliferation and differentiation to replenish the lost epithelium, and subsequently re-establish homeostasis [145-147]. This rapid and effective regeneration process depends on multiple signaling pathways, including $\mathrm{Wg}$.

Following exposure to cytotoxic agents or bacterial infection, the level of Wg protein increases markedly in EBs of the midgut epithelium and induces compensatory proliferation of ISCs, whereas wg knockdown strongly impairs this response [113]. Similarly, the abrogation of Wg signaling in the intestinal epithelium abolishes gut regeneration [113]. Thus, upregulation of $\mathrm{Wg}$ levels and activation of the Wg pathway in the intestinal epithelium are essential for damage-induced regeneration of the Drosophila midgut.

In contrast to the midgut, the Drosophila adult hindgut lacks active stem cells, and, following damage, preserves epithelial integrity in part by endoreplication and cellular hypertrophy in the 
pylorus $[107,114,148]$. In addition, a unique population of ISCs in the posterior terminal midgut that are normally quiescent proliferate robustly following injury in the Wg-enriched MHB or the hindgut [107]. As noted above, epithelial Wg ligand is detected in the region of the MHB [106,107]. These Wg positive cells express both midgut and hindgut markers, and thus constitute a hybrid zone (HZ) between the midgut and hindgut [107]. In contrast to other ISCs in the midgut, ISCs that are located immediately anterior to the $\mathrm{HZ}$ are responsive to $\mathrm{Wg}$ stimulation even under homeostatic conditions [106,107] and have been termed organ boundary intestinal stem cells (OB-ISCs) [107]. Damage in the HZ and pylorus upregulates expression of the cytokine upd3 in the Wg-enriched HZ. In response, the OB-ISCs undergo both symmetric and asymmetric divisions to give rise to new OB-ISCs and enterocytes. When the injury of the HZ is severe, hyperplastic midgut OB-ISCs cross the MHB through gaps in the injured HZ [107]. Thus, the OB-ISCs are a unique population of Wg-responsive midgut ISCs that display robust cell proliferation in response to cell loss in the HZ and pylorus; however, whether their compensatory response requires $\mathrm{Wg}$ signaling awaits further investigation.

\subsection{Hyperactivation of Wg Signaling Due to Loss of Apc: Initiation and Progression of Tumorigenesis in the Drosophila Gut}

\subsubsection{Initiation of Intestinal Tumorigenesis upon Loss of Apc}

The Drosophila melanogaster genome encodes two Apc genes: Apc1 and Apc2 [149-154]. Either concomitant inactivation of both Drosophila Apc homologs, or inactivation of Apc1 singly, leads to overproliferation of ISCs, epithelial hyperplasia, and disrupted epithelial cell polarity, resulting in the formation of a multilayered epithelium [100,142,144,155-158]. These defects resemble mammalian intestinal adenomas that arise following loss of APC, highlighting the potential of using the Drosophila Apc1 mutant as a model to study colorectal cancers. In Apc1 mutants, ISC overproliferation begins during pupation, whereas the disruption of epithelial cell polarity occurs after eclosion [100]. Thus, the defects caused by loss of Apc1 begin during development and increase in severity during adulthood. These defects are mediated by the hyperactivation of Wg signaling, as knockdown of the transcriptional co-activator Pygopus, expression of dominant negative TCF, or the inactivation of two transcriptional regulators of the Wg pathway, Earthbound (Ebd) and Erect wing (Ewg), suppress the Apc1 mutant phenotype $[100,142,157]$.

Despite known roles for Apc2 in the mammalian intestine $[159,160]$, the role of Drosophila Apc2 and whether there exists some redundancy between Apc1 and Apc2 in the Drosophila midgut remains uncertain. One report suggested that functional redundancy exists between the two proteins, as inactivation of both $A p c 1$ and $A p c 2$ was required for ISC overproliferation, multilayering of the epithelium, and the upregulation of a Wg target gene reporter [157]. However, several other studies have revealed that inactivation of $A p c 1$ singly is sufficient to fully account for these effects of $\mathrm{Wg}$ pathway hyperactivation $[100,144,155]$.

\subsubsection{Progression of Intestinal Tumorigenesis Following Apc Loss}

As noted above, in mammals, the acquisition of additional mutations transforms pre-malignant adenomas to malignant carcinoma following the loss of APC [56-60]. Recent studies have recapitulated this tumor progression process in the Drosophila digestive tract and shed light on three underlying molecular mechanisms.

First, cell competition exists between Drosophila Apc1 Apc2 double mutant tumor cells and adjacent wild-type cells [156]. Epithelial cells bearing Apc mutations act as "super competitors", trigger apoptosis in the surrounding wild-type cells, clear space for dissemination, and result in host tissue attrition. Remarkably, inhibition of cell competition by the blocking of apoptosis prevents Apc mutant tumor expansion [156]. Thus, host-tumor cell competition is essential for tumor growth in $A p c$ mutant midguts. 
Second, two independent studies examined the effects of hyperactivated Ras in Apc mutant midgut cells (Apc1 Apc2-Ras V12 clones) [157,158]; both indicated that the oncogenic activation of Ras exacerbates the phenotypes caused by Apc loss alone. Specifically, Apc-Ras V12 double mutant clones exhibit hallmarks of malignant transformation that include the inhibition of cell differentiation, disruption of cell polarity, and invasive outgrowth. As a result, intestinal physiology deteriorates with time and lifespan is reduced. Therefore, oncogenic Ras activation synergizes with Apc loss to promote intestinal tumor progression $[157,158]$. Local juvenile hormone activity derived from the gut progenitors is required for this process [161].

Third, genome sequencing data not only confirmed that in human colorectal cancers, multiple mutations are acquired in addition to $A P C$, but also revealed that these mutations exist in distinct combinations in different tumors $[42,46,103,162,163]$. To examine the effect of genetic complexity and heterogeneity on gut tumor progression and drug response, a recent study took advantage of the powerful genetic tools that exist in Drosophila, generating 32 distinct multigenic (quadruples or quintuple) alterations that are based on patient tumor data [103]. The effects of these alterations were examined in the Drosophila hindgut, which revealed that the interaction between concurrent mutations promoted robust epithelial cell transformation. Moreover, drug resistance also emerged in these multigenic combinations. With the knowledge gained from these models, the order of drug treatment was manipulated to promote drug sensitivity in Drosophila tumor cells, and this approach was subsequently validated in mammalian models [103]. Together, these findings demonstrate that the Drosophila adult digestive tract recapitulates key events in both the initiation and progression of tumorigenesis following APC loss, and also offers a promising platform for both drug screening and the identification of novel tumor modifiers.

\section{The Drosophila Gut as a Powerful In Vivo Context to Test Novel Therapeutic Agents and Novel Wnt Pathway Components}

Our understanding of the roles of Wg signaling in Drosophila intestinal physiology and pathology has been greatly improved in recent years. These advances have, in return, prompted the use of the Drosophila gut as a powerful physiological context to examine both novel therapeutic agents and novel Wnt pathway components. Examples of such approaches targeting different levels of Wnt signaling are summarized below.

\subsection{At the Receptor Level: The Signalosome}

A recent study revealed, unexpectedly, that in APC-deficient colorectal carcinoma cells, blocking signalosome formation by knocking down $L R P 6, F z$, or $D V L$ reduces $\beta$-catenin nuclear accumulation and inhibits constitutive Wnt pathway activation. Thus, signalosome assembly is essential for aberrantly increased Wnt signaling following loss of APC [164,165]. This hypothesis was further tested in the in vivo context of Drosophila Apc1 mutant midguts. Notably, knocking down either arr or $d s h$ rescues $A p c 1$ mutant intestinal defects, including ISC overproliferation, epithelial cell polarity disruption, and aberrant activation of Wg target genes [164]. Thus, there exists an evolutionarily conserved dependence on signalosome assembly for Wnt pathway hyperactivation following the loss of APC. This process requires clathrin-mediated endocytosis, but is independent of Wnt ligands [164].

\subsection{In the Cytoplasm: Tankyrase}

Tankyrase (Tnks) is an ADP-ribose polymerase that targets Axin for proteolysis [69,72]. Small molecule inhibitors of Tnks disrupt Wnt signaling in cultured human cells and reduce colonic adenoma growth in mouse models, suggesting that Tnks is a promising therapeutic candidate for the treatment of Wnt-driven cancers [68-73]. However, the physiological settings in which Tnks is required to promote Wnt signaling had been unclear $[68,69,166]$. One of the complications is functional redundancy in the two Tnks paralogs in vertebrates [167]. Drosophila genomes encode only one Tnks, which is highly conserved with its vertebrate homologs. Capitalizing on Drosophila genetics, null alleles of 
Tnks were generated. In conditions of limited nutrient supply, these Tnks mutant adults displayed markedly increased mortality, suggesting disrupted digestive function [101]. Examination of the adult intestines from Tnks null mutants revealed several physiological requirements [101]. First, Tnks is crucial to maintain Axin levels below a physiological threshold and this is essential for the control of ISC proliferation; Tnks mutants display severe ISC overproliferation. Second, Tnks is essential to ensure proper activation of $\mathrm{Wg}$ signaling in the midgut, which provided the first in vivo evidence that regulation of Axin by Tnks is required for $\mathrm{Wg}$ target gene activation in a physiological context. Notably, this requirement for Tnks in Wg pathway activation is spatially restricted: Tnks is essential for $\mathrm{Wg}$ signaling only in regions where $\mathrm{Wg}$ pathway activity is relatively low, but is dispensable where pathway activity is high, reflecting the role of Tnks in the amplification of $\mathrm{Wg}$ signaling in vivo.

\subsection{In the Nucleus: Earthbound and Erect Wing}

Due to the requirements for Wnt signaling in both normal homeostasis and Wnt-driven cancers, one of the major challenges for the therapeutic targeting of this pathway is to concomitantly achieve efficacy and specificity $[2,23,62,74]$. The discovery of transcription cofactors that are essential for hyperactivated signaling but dispensable for physiological processes distinguished tumors from normal tissues [168-176]. Through a forward genetic screen in Drosophila, two novel suppressors of Apc1, Earthbound (Ebd) and Erect wing (Ewg), were identified as evolutionarily conserved transcription cofactors of the Wnt pathway that physically interact with each other and with Armadillo-Tcf $[177,178]$. Remarkably, both Ebd and Ewg are essential mediators of the pathological consequences of Apc1 inactivation in the intestine: aberrantly increased number of progenitors, defects in adhesion and epithelial polarity, disorganization of the intestinal architecture and widespread deregulation of $\mathrm{Wg}$ target gene expression. In contrast, during intestinal homeostasis, Ebd is required for the Wg-dependent control of ISC proliferation, whereas Ewg is dispensable [100]. Therefore, Ebd and Ewg are differentially required in physiological Wnt pathway activation versus oncogenic Wnt pathway hyperactivation following Apc1 loss, conferring mechanistic differences in the Wnt transcription machinery, and providing potential selectivity between normal tissues and tumors. In addition, these findings also provided in vivo evidence that the core $\beta$-catenin-TCF transcriptional machinery is insufficient for the transformation of intestinal epithelial cells in Apc1 mutants; cooperation of $\beta$-catenin-TCF with Ebd and Ewg is also necessary. Further, these findings suggest that the human homolog of Ebd, Jerky (also known as JRK or JH8) [177,179-184], and the human homolog of Ewg, Nuclear respiratory Factor 1 (NRF1) [178,185-187], may provide promising drug targets for the treatment of Wnt-driven cancers. Notably, Jerky was identified in a high-throughput RNAi screen that facilitates Wnt target gene activation in colon adenocarcinoma cells [188]. Two later studies validated this role of Jerky as a positive modulator in Wnt signaling in colon cancer cell lines and further revealed that this is achieved by promoting the association of $\beta$-catenin and TCF and the recruitment of $\beta$-catenin to chromatin $[177,189]$. Moreover, aberrantly high levels of Jerky are present in human colorectal tumors [189]. A possible role for NRF1 in Wnt signaling awaits future investigation.

\section{Crosstalk between Wg Signaling and Other Signaling Pathways in the Drosophila Gut}

Several signaling pathways are involved in Drosophila intestinal physiology and pathology, thus weaving an intricate regulation network [190]. Recent studies have revealed the crosstalk between Wg signaling and other signaling pathways during homeostasis, regeneration, and tumorigenesis.

First, during homeostasis, Wg signaling prevents the aberrant activation of the JAK-STAT pathway [106]. Specifically, diminishing Wg signaling results in a marked increase in the expression of the JAK-STAT pathway ligands Upd2 and Upd3 in the enterocytes, which in turn triggers the aberrant activation of JAK-STAT signaling in the neighboring ISCs and drives their non-autonomous overproliferation. 
Second, damage to the intestinal epithelium leads to the overactivation of the JNK pathway and at the same time also results in increased levels of the Wg ligand [113,191]. This upregulation of Wg is dependent on JNK pathway activation, but not vice versa, thus placing Wg signaling downstream of JNK pathway activation during the regeneration process [113].

Third, both the JAK-STAT pathway and the EGFR pathway are hyperactivated in the Drosophila gut upon loss of Apc1 [144]. Remarkably, disruption of either JAK-STAT signaling or EGFR signaling completely suppresses the intestinal hyperplasia resulting from Apc1 loss, revealing the underlying signaling networks at the tumor initiation step.

\section{Conclusions}

The evolutionary conservation of Wnt/Wingless signaling and the similarities between the Drosophila and mammalian digestive tracts have made the Drosophila gut a powerful model to study intestinal physiology and pathology. Recent advances have uncovered critical roles for Wg signaling in development, homeostasis, and regeneration of the Drosophila adult gut. Furthermore, the Drosophila gut has become a model for colorectal tumorigenesis. As the Drosophila gut has proven to be an effective platform for drug screens [102,103], Apc1 mutant guts could serve as a potential platform to identify novel compounds that combat Wnt-driven cancers. In addition, recent work has revealed the importance of the Drosophila gut model for elucidating context-specific functions of newly identified Wg pathway components. Lastly, the unique characteristics of the adult gut have been advantageous for tackling basic questions in cell biology, including cell-cell competition and interorgan communication.

\section{Future Perspectives}

Many questions remain, including how Wg signaling gradients are established at the compartment boundaries, how they are maintained during the normal turnover of the intestinal epithelium, and how they recover following injury. In addition, whereas it is known that ISCs residing in distinct compartments along the anterior-posterior axis of the Drosophila gut have different identities and exhibit different proliferate rates [81,82], whether distinct $\mathrm{Wg}$ responses exist among these different ISC populations awaits investigation. Moreover, how Wg interfaces with other signaling pathways that are known to regulate development, homeostasis, and regeneration of the adult gut remains an open question. The powerful genetic techniques that have been developed to dissect the biology of the Drosophila gut will pave the way for future studies that address these questions, shedding more light on a pathway that is critical for development and disease.

Acknowledgments: We thank the reviewers and Nicholas Tolwinski for comments. This work was funded by the NIH (R01GM121421 and R01GM122222 to YA).

Author Contributions: A.T., H.B. and Y.A wrote the manuscript.

Conflicts of Interest: The authors declare no conflict of interest.

\section{References}

1. Gammons, M.; Bienz, M. Multiprotein complexes governing wnt signal transduction. Curr. Opin. Cell Biol. 2017, 51, 42-49. [CrossRef] [PubMed]

2. Nusse, R.; Clevers, H. Wnt/beta-catenin signaling, disease, and emerging therapeutic modalities. Cell 2017, 169, 985-999. [CrossRef] [PubMed]

3. Saito-Diaz, K.; Chen, T.W.; Wang, X.; Thorne, C.A.; Wallace, H.A.; Page-McCaw, A.; Lee, E. The way wnt works: Components and mechanism. Growth Factors 2013, 31, 1-31. [CrossRef] [PubMed]

4. Stamos, J.L.; Weis, W.I. The beta-catenin destruction complex. Cold Spring Harbor Perspect. Biol. 2013, 5, a007898. [CrossRef] [PubMed]

5. Langton, P.F.; Kakugawa, S.; Vincent, J.P. Making, exporting, and modulating wnts. Trends Cell Biol. 2016, 26, 756-765. [CrossRef] [PubMed] 
6. Jiang, X.; Cong, F. Novel regulation of wnt signaling at the proximal membrane level. Trends Biochem. Sci. 2016, 41, 773-783. [CrossRef] [PubMed]

7. MacDonald, B.T.; He, X. Frizzled and lrp5/6 receptors for wnt/beta-catenin signaling. Cold Spring Harbor Perspect. Biol. 2012, 4, a007880. [CrossRef] [PubMed]

8. De Bruine, Z.J.; Xu, H.E.; Melcher, K. Assembly and architecture of the wnt/beta-catenin signalosome at the membrane. Br. J. Pharmacol. 2017, 174, 4564-4574. [CrossRef] [PubMed]

9. Li, V.S.; Ng, S.S.; Boersema, P.J.; Low, T.Y.; Karthaus, W.R.; Gerlach, J.P.; Mohammed, S.; Heck, A.J.; Maurice, M.M.; Mahmoudi, T.; et al. Wnt signaling through inhibition of beta-catenin degradation in an intact axin1 complex. Cell 2012, 149, 1245-1256. [CrossRef] [PubMed]

10. Gerlach, J.P.; Emmink, B.L.; Nojima, H.; Kranenburg, O.; Maurice, M.M. Wnt signalling induces accumulation of phosphorylated beta-catenin in two distinct cytosolic complexes. Open Biol. 2014, 4, 140120. [CrossRef] [PubMed]

11. Masuda, T.; Ishitani, T. Context-dependent regulation of the beta-catenin transcriptional complex supports diverse functions of wnt/beta-catenin signaling. J. Biochem. 2017, 161, 9-17. [CrossRef] [PubMed]

12. Ramakrishnan, A.B.; Sinha, A.; Fan, V.B.; Cadigan, K.M. The wnt transcriptional switch: Tle removal or inactivation? BioEssays News Rev. Mol. Cell. Dev. Biol. 2018. [CrossRef] [PubMed]

13. Cadigan, K.M.; Waterman, M.L. Tcf/lefs and wnt signaling in the nucleus. Cold Spring Harbor Perspect. Biol. 2012, 4, a007906. [CrossRef]

14. Loh, K.M.; van Amerongen, R.; Nusse, R. Generating cellular diversity and spatial form: Wnt signaling and the evolution of multicellular animals. Dev. Cell 2016, 38, 643-655. [CrossRef] [PubMed]

15. Holstein, T.W. The evolution of the wnt pathway. Cold Spring Harbor Perspect. Biol. 2012, 4, a007922. [CrossRef] [PubMed]

16. Petersen, C.P.; Reddien, P.W. Wnt signaling and the polarity of the primary body axis. Cell 2009, 139, 1056-1068. [CrossRef] [PubMed]

17. Clevers, H.; Loh, K.M.; Nusse, R. Stem cell signaling. An integral program for tissue renewal and regeneration: Wnt signaling and stem cell control. Science 2014, 346, 1248012. [CrossRef] [PubMed]

18. Kretzschmar, K.; Clevers, H. Wnt/beta-catenin signaling in adult mammalian epithelial stem cells. Dev. Biol. 2017, 428, 273-282. [CrossRef] [PubMed]

19. Lien, W.H.; Fuchs, E. Wnt some lose some: Transcriptional governance of stem cells by wnt/beta-catenin signaling. Genes Dev. 2014, 28, 1517-1532. [CrossRef] [PubMed]

20. Bastakoty, D.; Young, P.P. Wnt/beta-catenin pathway in tissue injury: Roles in pathology and therapeutic opportunities for regeneration. FASEB J. 2016, 30, 3271-3284. [CrossRef] [PubMed]

21. Majidinia, M.; Aghazadeh, J.; Jahanban-Esfahlani, R.; Yousefi, B. The roles of wnt/beta-catenin pathway in tissue development and regenerative medicine. J. Cell. Physiol. 2017. [CrossRef]

22. Clevers, H.; Nusse, R. Wnt/beta-catenin signaling and disease. Cell 2012, 149, 1192-1205. [CrossRef]

23. Zhan, T.; Rindtorff, N.; Boutros, M. Wnt signaling in cancer. Oncogene 2017, 36, 1461-1473. [CrossRef] [PubMed]

24. Baron, R.; Kneissel, M. Wnt signaling in bone homeostasis and disease: From human mutations to treatments. Nat. Med. 2013, 19, 179-192. [CrossRef] [PubMed]

25. Krausova, M.; Korinek, V. Wnt signaling in adult intestinal stem cells and cancer. Cell. Signal. 2014, 26, 570-579. [CrossRef] [PubMed]

26. Schepers, A.; Clevers, H. Wnt signaling, stem cells, and cancer of the gastrointestinal tract. Cold Spring Harbor Perspect. Biol. 2012, 4, a007989. [CrossRef] [PubMed]

27. Siegel, R.L.; Miller, K.D.; Jemal, A. Cancer statistics, 2018. CA Cancer J. Clin. 2018, 68, 7-30. [CrossRef] [PubMed]

28. Ferlay, J.; Soerjomataram, I.; Dikshit, R.; Eser, S.; Mathers, C.; Rebelo, M.; Parkin, D.M.; Forman, D.; Bray, F. Cancer incidence and mortality worldwide: Sources, methods and major patterns in globocan 2012. Int. J. Cancer 2015, 136, E359-E386. [CrossRef] [PubMed]

29. Potten, C.S.; Morris, R.J. Epithelial stem-cells invivo. J. Cell Sci. 1988, 10, 45-62. [CrossRef]

30. Kosinski, C.; Li, V.S.; Chan, A.S.; Zhang, J.; Ho, C.; Tsui, W.Y.; Chan, T.L.; Mifflin, R.C.; Powell, D.W.; Yuen, S.T.; et al. Gene expression patterns of human colon tops and basal crypts and bmp antagonists as intestinal stem cell niche factors. Proc. Natl. Acad. Sci. USA 2007, 104, 15418-15423. [CrossRef] [PubMed] 
31. van de Wetering, M.; Sancho, E.; Verweij, C.; de Lau, W.; Oving, I.; Hurlstone, A.; van der Horn, K.; Batlle, E.; Coudreuse, D.; Haramis, A.P.; et al. The beta-catenin/tcf-4 complex imposes a crypt progenitor phenotype on colorectal cancer cells. Cell 2002, 111, 241-250. [CrossRef]

32. Gregorieff, A.; Pinto, D.; Begthel, H.; Destree, O.; Kielman, M.; Clevers, H. Expression pattern of wnt signaling components in the adult intestine. Gastroenterology 2005, 129, 626-638. [CrossRef] [PubMed]

33. Farin, H.F.; Jordens, I.; Mosa, M.H.; Basak, O.; Korving, J.; Tauriello, D.V.; de Punder, K.; Angers, S.; Peters, P.J.; Maurice, M.M.; et al. Visualization of a short-range wnt gradient in the intestinal stem-cell niche. Nature 2016, 530, 340-343. [CrossRef] [PubMed]

34. Fevr, T.; Robine, S.; Louvard, D.; Huelsken, J. Wnt/beta-catenin is essential for intestinal homeostasis and maintenance of intestinal stem cells. Mol. Cell. Biol. 2007, 27, 7551-7559. [CrossRef] [PubMed]

35. Ireland, H.; Kemp, R.; Houghton, C.; Howard, L.; Clarke, A.R.; Sansom, O.J.; Winton, D.J. Inducible cre-mediated control of gene expression in the murine gastrointestinal tract: Effect of loss of beta-catenin. Gastroenterology 2004, 126, 1236-1246. [CrossRef] [PubMed]

36. Kuhnert, F.; Davis, C.R.; Wang, H.T.; Chu, P.; Lee, M.; Yuan, J.; Nusse, R.; Kuo, C.J. Essential requirement for wnt signaling in proliferation of adult small intestine and colon revealed by adenoviral expression of dickkopf-1. Proc. Natl. Acad. Sci. USA 2004, 101, 266-271. [CrossRef] [PubMed]

37. Pinto, D.; Gregorieff, A.; Begthel, H.; Clevers, H. Canonical wnt signals are essential for homeostasis of the intestinal epithelium. Genes Dev. 2003, 17, 1709-1713. [CrossRef] [PubMed]

38. Korinek, V.; Barker, N.; Moerer, P.; van Donselaar, E.; Huls, G.; Peters, P.J.; Clevers, H. Depletion of epithelial stem-cell compartments in the small intestine of mice lacking tcf-4. Nat. Genet. 1998, 19, 379-383. [CrossRef] [PubMed]

39. van Es, J.H.; Haegebarth, A.; Kujala, P.; Itzkovitz, S.; Koo, B.K.; Boj, S.F.; Korving, J.; van den Born, M.; van Oudenaarden, A.; Robine, S.; et al. A critical role for the wnt effector tcf4 in adult intestinal homeostatic self-renewal. Mol. Cell. Biol. 2012, 32, 1918-1927. [CrossRef] [PubMed]

40. Kim, K.A.; Kakitani, M.; Zhao, J.; Oshima, T.; Tang, T.; Binnerts, M.; Liu, Y.; Boyle, B.; Park, E.; Emtage, P.; et al. Mitogenic influence of human r-spondin1 on the intestinal epithelium. Science 2005, 309, 1256-1259. [CrossRef] [PubMed]

41. Sato, T.; Vries, R.G.; Snippert, H.J.; van de Wetering, M.; Barker, N.; Stange, D.E.; van Es, J.H.; Abo, A.; Kujala, P.; Peters, P.J.; et al. Single lgr5 stem cells build crypt-villus structures in vitro without a mesenchymal niche. Nature 2009, 459, 262-265. [CrossRef] [PubMed]

42. The Cancer Genome Atlas Network. Comprehensive molecular characterization of human colon and rectal cancer. Nature 2012, 487, 330-337.

43. Groden, J.; Thliveris, A.; Samowitz, W.; Carlson, M.; Gelbert, L.; Albertsen, H.; Joslyn, G.; Stevens, J.; Spirio, L.; Robertson, M.; et al. Identification and characterization of the familial adenomatous polyposis-coli gene. Cell 1991, 66, 589-600. [CrossRef]

44. Kinzler, K.W.; Nilbert, M.C.; Su, L.K.; Vogelstein, B.; Bryan, T.M.; Levy, D.B.; Smith, K.J.; Preisinger, A.C.; Hedge, P.; McKechnie, D.; et al. Identification of fap locus genes from chromosome 5q21. Science 1991, 253, 661-665. [CrossRef] [PubMed]

45. Nishisho, I.; Nakamura, Y.; Miyoshi, Y.; Miki, Y.; Ando, H.; Horii, A.; Koyama, K.; Utsunomiya, J.; Baba, S.; Hedge, P. Mutations of chromosome 5q21 genes in fap and colorectal cancer patients. Science 1991, 253, 665-669. [CrossRef] [PubMed]

46. Wood, L.D.; Parsons, D.W.; Jones, S.; Lin, J.; Sjoblom, T.; Leary, R.J.; Shen, D.; Boca, S.M.; Barber, T.; Ptak, J.; et al. The genomic landscapes of human breast and colorectal cancers. Science 2007, 318, 1108-1113. [CrossRef] [PubMed]

47. Bass, A.J.; Lawrence, M.S.; Brace, L.E.; Ramos, A.H.; Drier, Y.; Cibulskis, K.; Sougnez, C.; Voet, D.; Saksena, G.; Sivachenko, A.; et al. Genomic sequencing of colorectal adenocarcinomas identifies a recurrent vtila-tcf7l2 fusion. Nat. Genet. 2011, 43, 964-968. [CrossRef] [PubMed]

48. Liu, W.; Dong, X.; Mai, M.; Seelan, R.S.; Taniguchi, K.; Krishnadath, K.K.; Halling, K.C.; Cunningham, J.M.; Boardman, L.A.; Qian, C.; et al. Mutations in axin2 cause colorectal cancer with defective mismatch repair by activating beta-catenin/tcf signalling. Nat. Genet. 2000, 26, 146-147. [CrossRef] [PubMed]

49. Morin, P.J.; Sparks, A.B.; Korinek, V.; Barker, N.; Clevers, H.; Vogelstein, B.; Kinzler, K.W. Activation of beta-catenin-tcf signaling in colon cancer by mutations in beta-catenin or apc. Science 1997, 275, 1787-1790. [CrossRef] [PubMed] 
50. Seshagiri, S.; Stawiski, E.W.; Durinck, S.; Modrusan, Z.; Storm, E.E.; Conboy, C.B.; Chaudhuri, S.; Guan, Y.; Janakiraman, V.; Jaiswal, B.S.; et al. Recurrent r-spondin fusions in colon cancer. Nature 2012, 488, 660-664. [CrossRef] [PubMed]

51. Mazzoni, S.M.; Fearon, E.R. Axin1 and axin2 variants in gastrointestinal cancers. Cancer Lett. 2014, 355, 1-8. [CrossRef] [PubMed]

52. Giannakis, M.; Hodis, E.; Jasmine Mu, X.; Yamauchi, M.; Rosenbluh, J.; Cibulskis, K.; Saksena, G.; Lawrence, M.S.; Qian, Z.R.; Nishihara, R.; et al. Rnf43 is frequently mutated in colorectal and endometrial cancers. Nat. Genet. 2014, 46, 1264-1266. [CrossRef] [PubMed]

53. Lum, L.; Clevers, H. Cell biology. The unusual case of porcupine. Science 2012, 337, 922-923. [CrossRef] [PubMed]

54. Koo, B.K.; Spit, M.; Jordens, I.; Low, T.Y.; Stange, D.E.; van de Wetering, M.; van Es, J.H.; Mohammed, S.; Heck, A.J.; Maurice, M.M.; et al. Tumour suppressor rnf43 is a stem-cell e3 ligase that induces endocytosis of wnt receptors. Nature 2012, 488, 665-669. [CrossRef] [PubMed]

55. Hao, H.X.; Xie, Y.; Zhang, Y.; Charlat, O.; Oster, E.; Avello, M.; Lei, H.; Mickanin, C.; Liu, D.; Ruffner, H.; et al. Znrf3 promotes wnt receptor turnover in an r-spondin-sensitive manner. Nature 2012, 485, 195-200. [CrossRef] [PubMed]

56. Kinzler, K.W.; Vogelstein, B. Lessons from hereditary colorectal cancer. Cell 1996, 87, 159-170. [CrossRef]

57. Fearon, E.R.; Vogelstein, B. A genetic model for colorectal tumorigenesis. Cell 1990, 61, 759-767. [CrossRef]

58. Janssen, K.P.; Alberici, P.; Fsihi, H.; Gaspar, C.; Breukel, C.; Franken, P.; Rosty, C.; Abal, M.; El Marjou, F.; Smits, R.; et al. Apc and oncogenic kras are synergistic in enhancing wnt signaling in intestinal tumor formation and progression. Gastroenterology 2006, 131, 1096-1109. [CrossRef] [PubMed]

59. Marsh, V.; Winton, D.J.; Williams, G.T.; Dubois, N.; Trumpp, A.; Sansom, O.J.; Clarke, A.R. Epithelial pten is dispensable for intestinal homeostasis but suppresses adenoma development and progression after apc mutation. Nat. Genet. 2008, 40, 1436-1444. [CrossRef] [PubMed]

60. Drost, J.; van Jaarsveld, R.H.; Ponsioen, B.; Zimberlin, C.; van Boxtel, R.; Buijs, A.; Sachs, N.; Overmeer, R.M.; Offerhaus, G.J.; Begthel, H.; et al. Sequential cancer mutations in cultured human intestinal stem cells. Nature 2015, 521, 43-47. [CrossRef] [PubMed]

61. Dow, L.E.; O’Rourke, K.P.; Simon, J.; Tschaharganeh, D.F.; van Es, J.H.; Clevers, H.; Lowe, S.W. Apc restoration promotes cellular differentiation and reestablishes crypt homeostasis in colorectal cancer. Cell 2015, 161, 1539-1552. [CrossRef] [PubMed]

62. Novellasdemunt, L.; Antas, P.; Li, V.S. Targeting wnt signaling in colorectal cancer. A review in the theme: Cell signaling: Proteins, pathways and mechanisms. Am. J. Physiol. Cell Physiol. 2015, 309, C511-C521. [CrossRef] [PubMed]

63. Krishnamurthy, N.; Kurzrock, R. Targeting the wnt/beta-catenin pathway in cancer: Update on effectors and inhibitors. Cancer Treat. Rev. 2018, 62, 50-60. [CrossRef] [PubMed]

64. Driehuis, E.; Clevers, H. Wnt signalling events near the cell membrane and their pharmacological targeting for the treatment of cancer. Br. J. Pharmacol. 2017, 174, 4547-4563. [CrossRef] [PubMed]

65. van Kappel, E.C.; Maurice, M.M. Molecular regulation and pharmacological targeting of the beta-catenin destruction complex. Br. J. Pharmacol. 2017, 174, 4575-4588. [CrossRef] [PubMed]

66. Lyou, Y.; Habowski, A.N.; Chen, G.T.; Waterman, M.L. Inhibition of nuclear wnt signalling: Challenges of an elusive target for cancer therapy. Br. J. Pharmacol. 2017, 174, 4589-4599. [CrossRef] [PubMed]

67. Zimmerli, D.; Hausmann, G.; Cantu, C.; Basler, K. Pharmacological interventions in the wnt pathway: Inhibition of wnt secretion versus disrupting the protein-protein interfaces of nuclear factors. Br. J. Pharmacol. 2017, 174, 4600-4610. [CrossRef] [PubMed]

68. Chen, B.; Dodge, M.E.; Tang, W.; Lu, J.; Ma, Z.; Fan, C.W.; Wei, S.; Hao, W.; Kilgore, J.; Williams, N.S.; et al. Small molecule-mediated disruption of wnt-dependent signaling in tissue regeneration and cancer. Nat. Chem. Biol. 2009, 5, 100-107. [CrossRef] [PubMed]

69. Huang, S.M.; Mishina, Y.M.; Liu, S.; Cheung, A.; Stegmeier, F.; Michaud, G.A.; Charlat, O.; Wiellette, E.; Zhang, Y.; Wiessner, S.; et al. Tankyrase inhibition stabilizes axin and antagonizes wnt signalling. Nature 2009, 461, 614-620. [CrossRef] [PubMed] 
70. Waaler, J.; Machon, O.; Tumova, L.; Dinh, H.; Korinek, V.; Wilson, S.R.; Paulsen, J.E.; Pedersen, N.M.; Eide, T.J.; Machonova, O.; et al. A novel tankyrase inhibitor decreases canonical wnt signaling in colon carcinoma cells and reduces tumor growth in conditional apc mutant mice. Cancer Res. 2012, 72, 2822-2832. [CrossRef] [PubMed]

71. Waaler, J.; Machon, O.; von Kries, J.P.; Wilson, S.R.; Lundenes, E.; Wedlich, D.; Gradl, D.; Paulsen, J.E.; Machonova, O.; Dembinski, J.L.; et al. Novel synthetic antagonists of canonical wnt signaling inhibit colorectal cancer cell growth. Cancer Res. 2011, 71, 197-205. [CrossRef] [PubMed]

72. Mariotti, L.; Pollock, K.; Guettler, S. Regulation of wnt/beta-catenin signalling by tankyrase-dependent poly(adp-ribosyl)ation and scaffolding. Br. J. Pharmacol. 2017, 174, 4611-4636. [CrossRef] [PubMed]

73. Lau, T.; Chan, E.; Callow, M.; Waaler, J.; Boggs, J.; Blake, R.A.; Magnuson, S.; Sambrone, A.; Schutten, M.; Firestein, R.; et al. A novel tankyrase small-molecule inhibitor suppresses apc mutation-driven colorectal tumor growth. Cancer Res. 2013, 73, 3132-3144. [CrossRef] [PubMed]

74. Kahn, M. Can we safely target the wnt pathway? Nat. Rev. Drug Discov. 2014, 13, 513-532. [CrossRef] [PubMed]

75. Karasov, W.H.; Martinez del Rio, C.; Caviedes-Vidal, E. Ecological physiology of diet and digestive systems. Annu. Rev. Physiol. 2011, 73, 69-93. [CrossRef] [PubMed]

76. Stainier, D.Y.R. No organ left behind: Tales of gut development and evolution. Science 2005, 307, $1902-1904$. [CrossRef] [PubMed]

77. San Roman, A.K.; Shivdasani, R.A. Boundaries, junctions and transitions in the gastrointestinal tract. Exp. Cell Res. 2011, 317, 2711-2718. [CrossRef] [PubMed]

78. Yasugi, S.; Mizuno, T. Molecular analysis of endoderm regionalization. Dev. Growth Differ. 2008, 50 (Suppl. 1), S79-S96. [CrossRef] [PubMed]

79. Li, X.; Udager, A.M.; Hu, C.; Qiao, X.T.; Richards, N.; Gumucio, D.L. Dynamic patterning at the pylorus: Formation of an epithelial intestine-stomach boundary in late fetal life. Dev. Dyn. 2009, 238, 3205-3217. [CrossRef] [PubMed]

80. Thompson, C.A.; Delaforest, A.; Battle, M.A. Patterning the gastrointestinal epithelium to confer regional-specific functions. Dev. Biol. 2018, 435, 97-108. [CrossRef] [PubMed]

81. Buchon, N.; Osman, D.; David, F.P.; Fang, H.Y.; Boquete, J.P.; Deplancke, B.; Lemaitre, B. Morphological and molecular characterization of adult midgut compartmentalization in drosophila. Cell Rep. 2013, 3, 1725-1738. [CrossRef] [PubMed]

82. Marianes, A.; Spradling, A.C. Physiological and stem cell compartmentalization within the drosophila midgut. eLife 2013, 2, e00886. [CrossRef] [PubMed]

83. O'Brien, L.E. Regional specificity in the drosophila midgut: Setting boundaries with stem cells. Cell Stem Cell 2013, 13, 375-376. [CrossRef] [PubMed]

84. Dutta, D.; Dobson, A.J.; Houtz, P.L.; Glasser, C.; Revah, J.; Korzelius, J.; Patel, P.H.; Edgar, B.A.; Buchon, N. Regional cell-specific transcriptome mapping reveals regulatory complexity in the adult drosophila midgut. Cell Rep. 2015, 12, 346-358. [CrossRef] [PubMed]

85. Lemaitre, B.; Miguel-Aliaga, I. The digestive tract of drosophila melanogaster. Annu. Rev. Genet. 2013, 47, 377-404. [CrossRef] [PubMed]

86. Buchon, N.; Osman, D. All for one and one for all: Regionalization of the drosophila intestine. Insect Biochem. Mol. 2015, 67, 2-8. [CrossRef] [PubMed]

87. Micchelli, C.A.; Perrimon, N. Evidence that stem cells reside in the adult drosophila midgut epithelium. Nature 2006, 439, 475-479. [CrossRef] [PubMed]

88. Ohlstein, B.; Spradling, A. The adult drosophila posterior midgut is maintained by pluripotent stem cells. Nature 2006, 439, 470-474. [CrossRef] [PubMed]

89. Biteau, B.; Jasper, H. Slit/robo signaling regulates cell fate decisions in the intestinal stem cell lineage of drosophila. Cell Rep. 2014, 7, 1867-1875. [CrossRef] [PubMed]

90. Zeng, X.; Hou, S.X. Enteroendocrine cells are generated from stem cells through a distinct progenitor in the adult drosophila posterior midgut. Development 2015, 142, 644-653. [CrossRef] [PubMed]

91. Zielke, N.; Korzelius, J.; van Straaten, M.; Bender, K.; Schuhknecht, G.F.; Dutta, D.; Xiang, J.; Edgar, B.A. Fly-fucci: A versatile tool for studying cell proliferation in complex tissues. Cell Rep. 2014, 7, 588-598. [CrossRef] [PubMed] 
92. Cadigan, K.M.; Peifer, M. Wnt signaling from development to disease: Insights from model systems. Cold Spring Harbor Perspect. Biol. 2009, 1, a002881. [CrossRef] [PubMed]

93. Swarup, S.; Verheyen, E.M. Wnt/wingless signaling in drosophila. Cold Spring Harbor Perspect. Biol. 2012, 4, a007930. [CrossRef] [PubMed]

94. Jenny, F.H.; Basler, K. Powerful drosophila screens that paved the wingless pathway. Fly 2014, 8, $218-225$. [CrossRef] [PubMed]

95. Vincent, J.P. Modulating and measuring wingless signalling. Methods 2014, 68, 194-198. [CrossRef] [PubMed]

96. Singh, S.R.; Mishra, M.K.; Kango-Singh, M.; Hou, S.X. Generation and staining of intestinal stem cell lineage in adult midgut. Methods Mol. Biol. 2012, 879, 47-69. [PubMed]

97. Micchelli, C.A. Whole-mount immunostaining of the adult drosophila gastrointestinal tract. Methods 2014, 68, 273-279. [CrossRef] [PubMed]

98. Dutta, D.; Buchon, N.; Xiang, J.; Edgar, B.A. Regional cell specific rna expression profiling of facs isolated drosophila intestinal cell populations. Curr. Protoc. Stem Cell Biol. 2015, 34. [CrossRef]

99. Houtz, P.L.; Buchon, N. Methods to assess intestinal stem cell activity in response to microbes in drosophila melanogaster. Methods Mol. Biol. 2014, 1213, 171-182. [PubMed]

100. Tian, A.; Benchabane, H.; Wang, Z.; Zimmerman, C.; Xin, N.; Perochon, J.; Kalna, G.; Sansom, O.J.; Cheng, C.; Cordero, J.B.; et al. Intestinal stem cell overproliferation resulting from inactivation of the apc tumor suppressor requires the transcription cofactors earthbound and erect wing. PLoS Genet. 2017, 13, e1006870. [CrossRef] [PubMed]

101. Wang, Z.; Tian, A.; Benchabane, H.; Tacchelly-Benites, O.; Yang, E.; Nojima, H.; Ahmed, Y. The adp-ribose polymerase tankyrase regulates adult intestinal stem cell proliferation during homeostasis in drosophila. Development 2016, 143, 1710-1720. [CrossRef] [PubMed]

102. Markstein, M.; Dettorre, S.; Cho, J.; Neumuller, R.A.; Craig-Muller, S.; Perrimon, N. Systematic screen of chemotherapeutics in drosophila stem cell tumors. Proc. Natl. Acad. Sci. USA 2014, 111, 4530-4535. [CrossRef] [PubMed]

103. Bangi, E.; Murgia, C.; Teague, A.G.; Sansom, O.J.; Cagan, R.L. Functional exploration of colorectal cancer genomes using drosophila. Nat. Commun. 2016, 7, 13615. [CrossRef] [PubMed]

104. Lin, G.; Xu, N.; Xi, R. Paracrine wingless signalling controls self-renewal of drosophila intestinal stem cells. Nature 2008, 455, 1119-1123. [CrossRef] [PubMed]

105. Struhl, G.; Basler, K. Organizing activity of wingless protein in drosophila. Cell 1993, 72, 527-540. [CrossRef]

106. Tian, A.; Benchabane, H.; Wang, Z.; Ahmed, Y. Regulation of stem cell proliferation and cell fate specification by wingless/wnt signaling gradients enriched at adult intestinal compartment boundaries. PLoS Genet. 2016, 12, e1005822. [CrossRef] [PubMed]

107. Sawyer, J.K.; Cohen, E.; Fox, D.T. Interorgan regulation of drosophila intestinal stem cell proliferation by a hybrid organ boundary zone. Development 2017, 144, 4091-4102. [CrossRef] [PubMed]

108. Kassis, J.A.; Noll, E.; VanSickle, E.P.; Odenwald, W.F.; Perrimon, N. Altering the insertional specificity of a drosophila transposable element. Proc. Natl. Acad. Sci. USA 1992, 89, 1919-1923. [CrossRef] [PubMed]

109. Singh, S.R.; Zeng, X.; Zheng, Z.; Hou, S.X. The adult drosophila gastric and stomach organs are maintained by a multipotent stem cell pool at the foregut/midgut junction in the cardia (proventriculus). Cell Cycle 2011, 10, 1109-1120. [CrossRef] [PubMed]

110. Takashima, S.; Mkrtchyan, M.; Younossi-Hartenstein, A.; Merriam, J.R.; Hartenstein, V. The behaviour of drosophila adult hindgut stem cells is controlled by wnt and hh signalling. Nature 2008, 454, 651-655. [CrossRef] [PubMed]

111. Alexandre, C.; Baena-Lopez, A.; Vincent, J.P. Patterning and growth control by membrane-tethered wingless. Nature 2014, 505, 180-185. [CrossRef] [PubMed]

112. Perea, D.; Guiu, J.; Hudry, B.; Konstantinidou, C.; Milona, A.; Hadjieconomou, D.; Carroll, T.; Hoyer, N.; Natarajan, D.; Kallijarvi, J.; et al. Ret receptor tyrosine kinase sustains proliferation and tissue maturation in intestinal epithelia. EMBO J. 2017, 36, 3029-3045. [CrossRef] [PubMed]

113. Cordero, J.B.; Stefanatos, R.K.; Scopelliti, A.; Vidal, M.; Sansom, O.J. Inducible progenitor-derived wingless regulates adult midgut regeneration in drosophila. EMBO J. 2012, 31, 3901-3917. [CrossRef] [PubMed]

114. Fox, D.T.; Spradling, A.C. The drosophila hindgut lacks constitutively active adult stem cells but proliferates in response to tissue damage. Cell Stem Cell 2009, 5, 290-297. [CrossRef] [PubMed]

115. Miller, J.R. The wnts. Genome Biol. 2002, 3, REVIEWS3001. [PubMed] 
116. Sato, A.; Kojima, T.; Ui-Tei, K.; Miyata, Y.; Saigo, K. Dfrizzled-3, a new drosophila wnt receptor, acting as an attenuator of wingless signaling in wingless hypomorphic mutants. Development 1999, 126, 4421-4430. [PubMed]

117. Sivasankaran, R.; Calleja, M.; Morata, G.; Basler, K. The wingless target gene dfz3 encodes a new member of the drosophila frizzled family. Mech. Dev. 2000, 91, 427-431. [CrossRef]

118. Zeng, W.; Wharton, K.A., Jr.; Mack, J.A.; Wang, K.; Gadbaw, M.; Suyama, K.; Klein, P.S.; Scott, M.P. Naked cuticle encodes an inducible antagonist of wnt signalling. Nature 2000, 403, 789-795. [CrossRef] [PubMed]

119. Olson, E.R.; Pancratov, R.; Chatterjee, S.S.; Changkakoty, B.; Pervaiz, Z.; DasGupta, R. Yan, an ets-domain transcription factor, negatively modulates the wingless pathway in the drosophila eye. EMBO Rep. 2011, 12, 1047-1054. [CrossRef]

120. Wang, X.; Page-McCaw, A. A matrix metalloproteinase mediates long-distance attenuation of stem cell proliferation. J. Cell Biol. 2014, 206, 923-936. [CrossRef] [PubMed]

121. Pancratov, R.; Peng, F.; Smibert, P.; Yang, J.S.; Olson, E.R.; Guha-Gilford, C.; Kapoor, A.J.; Liang, F.X.; Lai, E.C.; Flaherty, M.S.; et al. The mir-310/13 cluster antagonizes beta-catenin function in the regulation of germ and somatic cell differentiation in the drosophila testis. Development 2013, 140, 2904-2916. [CrossRef] [PubMed]

122. Reilein, A.; Melamed, D.; Park, K.S.; Berg, A.; Cimetta, E.; Tandon, N.; Vunjak-Novakovic, G.; Finkelstein, S.; Kalderon, D. Alternative direct stem cell derivatives defined by stem cell location and graded wnt signalling. Nat. Cell Biol. 2017, 19, 433-444. [CrossRef] [PubMed]

123. Zhang, T.; Hsu, F.N.; Xie, X.J.; Li, X.; Liu, M.; Gao, X.; Pei, X.; Liao, Y.; Du, W.; Ji, J.Y. Reversal of hyperactive wnt signaling-dependent adipocyte defects by peptide boronic acids. Proc. Natl. Acad. Sci. USA 2017, 114, E7469-E7478. [CrossRef] [PubMed]

124. Demerec, M. Biology of Drosophila; Wiley: New York, NY, USA, 1950; 632p.

125. Hakim, R.S.; Baldwin, K.; Smagghe, G. Regulation of midgut growth, development, and metamorphosis. Annu. Rev. Entomol. 2010, 55, 593-608. [CrossRef] [PubMed]

126. Micchelli, C.A. The origin of intestinal stem cells in drosophila. Dev. Dyn. 2012, 241, 85-91. [CrossRef] [PubMed]

127. Micchelli, C.A.; Sudmeier, L.; Perrimon, N.; Tang, S.; Beehler-Evans, R. Identification of adult midgut precursors in drosophila. Gene Expr. Patterns 2011, 11, 12-21. [CrossRef] [PubMed]

128. Jiang, H.; Edgar, B.A. Egfr signaling regulates the proliferation of drosophila adult midgut progenitors. Development 2009, 136, 483-493. [CrossRef] [PubMed]

129. Mathur, D.; Bost, A.; Driver, I.; Ohlstein, B. A transient niche regulates the specification of drosophila intestinal stem cells. Science 2010, 327, 210-213. [CrossRef] [PubMed]

130. Takashima, S.; Adams, K.L.; Ortiz, P.A.; Ying, C.T.; Moridzadeh, R.; Younossi-Hartenstein, A.; Hartenstein, V. Development of the drosophila entero-endocrine lineage and its specification by the notch signaling pathway. Dev. Biol. 2011, 353, 161-172. [CrossRef] [PubMed]

131. Denton, D.; Shravage, B.; Simin, R.; Mills, K.; Berry, D.L.; Baehrecke, E.H.; Kumar, S. Autophagy, not apoptosis, is essential for midgut cell death in drosophila. Curr. Biol. CB 2009, 19, 1741-1746. [CrossRef] [PubMed]

132. Takashima, S.; Paul, M.; Aghajanian, P.; Younossi-Hartenstein, A.; Hartenstein, V. Migration of drosophila intestinal stem cells across organ boundaries. Development 2013, 140, 1903-1911. [CrossRef] [PubMed]

133. Driver, I.; Ohlstein, B. Specification of regional intestinal stem cell identity during drosophila metamorphosis. Development 2014, 141, 1848-1856. [CrossRef] [PubMed]

134. Takashima, S.; Aghajanian, P.; Younossi-Hartenstein, A.; Hartenstein, V. Origin and dynamic lineage characteristics of the developing drosophila midgut stem cells. Dev. Biol. 2016, 416, 347-360. [CrossRef] [PubMed]

135. Takashima, S.; Younossi-Hartenstein, A.; Ortiz, P.A.; Hartenstein, V. A novel tissue in an established model system: The drosophila pupal midgut. Dev. Genes Evol. 2011, 221, 69-81. [CrossRef] [PubMed]

136. Guo, Z.; Ohlstein, B. Stem cell regulation. Bidirectional notch signaling regulates drosophila intestinal stem cell multipotency. Science 2015, 350. [CrossRef] [PubMed]

137. Aghajanian, P.; Takashima, S.; Paul, M.; Younossi-Hartenstein, A.; Hartenstein, V. Metamorphosis of the drosophila visceral musculature and its role in intestinal morphogenesis and stem cell formation. Dev. Biol. 2016, 420, 43-59. [CrossRef] [PubMed] 
138. Klapper, R. The longitudinal visceral musculature of drosophila melanogaster persists through metamorphosis. Mech. Dev. 2000, 95, 47-54. [CrossRef]

139. Kuroda, J.; Nakamura, M.; Yoshida, M.; Yamamoto, H.; Maeda, T.; Taniguchi, K.; Nakazawa, N.; Hatori, R.; Ishio, A.; Ozaki, A.; et al. Canonical wnt signaling in the visceral muscle is required for left-right asymmetric development of the drosophila midgut. Mech. Dev. 2012, 128, 625-639. [CrossRef] [PubMed]

140. Takashima, S.; Murakami, R. Regulation of pattern formation in the drosophila hindgut by wg, hh, dpp, and en. Mech. Dev. 2001, 101, 79-90. [CrossRef]

141. Hoppler, S.; Bienz, M. Two different thresholds of wingless signalling with distinct developmental consequences in the drosophila midgut. EMBO J. 1995, 14, 5016-5026. [PubMed]

142. Lee, W.C.; Beebe, K.; Sudmeier, L.; Micchelli, C.A. Adenomatous polyposis coli regulates drosophila intestinal stem cell proliferation. Development 2009, 136, 2255-2264. [CrossRef] [PubMed]

143. Strand, M.; Micchelli, C.A. Quiescent gastric stem cells maintain the adult drosophila stomach. Proc. Natl. Acad. Sci. USA 2011, 108, 17696-17701. [CrossRef] [PubMed]

144. Cordero, J.B.; Stefanatos, R.K.; Myant, K.; Vidal, M.; Sansom, O.J. Non-autonomous crosstalk between the jak/stat and egfr pathways mediates apc1-driven intestinal stem cell hyperplasia in the drosophila adult midgut. Development 2012, 139, 4524-4535. [CrossRef] [PubMed]

145. Buchon, N.; Broderick, N.A.; Lemaitre, B. Gut homeostasis in a microbial world: Insights from drosophila melanogaster. Nat. Rev. Microbiol. 2013, 11, 615-626. [CrossRef] [PubMed]

146. Jiang, H.; Tian, A.; Jiang, J. Intestinal stem cell response to injury: Lessons from drosophila. Cell. Mol. Life Sci. CMLS 2016, 73, 3337-3349. [CrossRef] [PubMed]

147. Liu, X.; Hodgson, J.J.; Buchon, N. Drosophila as a model for homeostatic, antibacterial, and antiviral mechanisms in the gut. PLoS Pathog. 2017, 13, e1006277. [CrossRef] [PubMed]

148. Losick, V.P.; Fox, D.T.; Spradling, A.C. Polyploidization and cell fusion contribute to wound healing in the adult drosophila epithelium. Curr. Biol. CB 2013, 23, 2224-2232. [CrossRef] [PubMed]

149. Ahmed, Y.; Hayashi, S.; Levine, A.; Wieschaus, E. Regulation of armadillo by a drosophila apc inhibits neuronal apoptosis during retinal development. Cell 1998, 93, 1171-1182. [CrossRef]

150. Ahmed, Y.; Nouri, A.; Wieschaus, E. Drosophila apc1 and apc2 regulate wingless transduction throughout development. Development 2002, 129, 1751-1762. [PubMed]

151. Akong, K.; Grevengoed, E.E.; Price, M.H.; McCartney, B.M.; Hayden, M.A.; DeNofrio, J.C.; Peifer, M. Drosophila apc2 and apc1 play overlapping roles in wingless signaling in the embryo and imaginal discs. Dev. Biol. 2002, 250, 91-100. [CrossRef] [PubMed]

152. Hayashi, S.; Rubinfeld, B.; Souza, B.; Polakis, P.; Wieschaus, E.; Levine, A.J. A drosophila homolog of the tumor suppressor gene adenomatous polyposis coli down-regulates beta-catenin but its zygotic expression is not essential for the regulation of armadillo. Proc. Natl. Acad. Sci. USA 1997, 94, 242-247. [CrossRef] [PubMed]

153. McCartney, B.M.; Dierick, H.A.; Kirkpatrick, C.; Moline, M.M.; Baas, A.; Peifer, M.; Bejsovec, A. Drosophila apc2 is a cytoskeletally-associated protein that regulates wingless signaling in the embryonic epidermis. J. Cell Biol. 1999, 146, 1303-1318. [CrossRef] [PubMed]

154. Yu, X.; Waltzer, L.; Bienz, M. A new drosophila apc homologue associated with adhesive zones of epithelial cells. Nat. Cell Biol. 1999, 1, 144-151. [CrossRef] [PubMed]

155. Cordero, J.; Vidal, M.; Sansom, O. Apc as a master regulator of intestinal homeostasis and transformation: From flies to vertebrates. Cell Cycle 2009, 8, 2926-2931. [CrossRef] [PubMed]

156. Suijkerbuijk, S.J.; Kolahgar, G.; Kucinski, I.; Piddini, E. Cell competition drives the growth of intestinal adenomas in drosophila. Curr. Biol. CB 2016, 26, 428-438. [CrossRef] [PubMed]

157. Wang, C.; Zhao, R.; Huang, P.; Yang, F.; Quan, Z.; Xu, N.; Xi, R. Apc loss-induced intestinal tumorigenesis in drosophila: Roles of ras in wnt signaling activation and tumor progression. Dev. Biol. 2013, 378, 122-140. [CrossRef] [PubMed]

158. Martorell, O.; Merlos-Suarez, A.; Campbell, K.; Barriga, F.M.; Christov, C.P.; Miguel-Aliaga, I.; Batlle, E.; Casanova, J.; Casali, A. Conserved mechanisms of tumorigenesis in the drosophila adult midgut. PLoS ONE 2014, 9, e88413. [CrossRef] [PubMed]

159. Young, M.A.; Daly, C.S.; Taylor, E.; James, R.; Clarke, A.R.; Reed, K.R. Subtle deregulation of the wnt-signaling pathway through loss of apc2 reduces the fitness of intestinal stem cells. Stem Cells 2018, 36, 114-122. [CrossRef] [PubMed] 
160. Nakagawa, H.; Murata, Y.; Koyama, K.; Fujiyama, A.; Miyoshi, Y.; Monden, M.; Akiyama, T.; Nakamura, Y. Identification of a brain-specific apc homologue, apcl, and its interaction with beta-catenin. Cancer Res. 1998, 58, 5176-5181. [PubMed]

161. Rahman, M.M.; Franch-Marro, X.; Maestro, J.L.; Martin, D.; Casali, A. Local juvenile hormone activity regulates gut homeostasis and tumor growth in adult drosophila. Sci. Rep. 2017, 7, 11677. [CrossRef] [PubMed]

162. Leary, R.J.; Lin, J.C.; Cummins, J.; Boca, S.; Wood, L.D.; Parsons, D.W.; Jones, S.; Sjoblom, T.; Park, B.H.; Parsons, R.; et al. Integrated analysis of homozygous deletions, focal amplifications, and sequence alterations in breast and colorectal cancers. Proc. Natl. Acad. Sci. USA 2008, 105, 16224-16229. [CrossRef] [PubMed]

163. Sjoblom, T.; Jones, S.; Wood, L.D.; Parsons, D.W.; Lin, J.; Barber, T.D.; Mandelker, D.; Leary, R.J.; Ptak, J.; Silliman, N.; et al. The consensus coding sequences of human breast and colorectal cancers. Science 2006, 314, 268-274. [CrossRef] [PubMed]

164. Saito-Diaz, K.; Benchabane, H.; Tiwari, A.; Tian, A.; Li, B.; Thompson, J.J.; Hyde, A.S.; Sawyer, L.M.; Jodoin, J.N.; Santos, E.; et al. Apc inhibits ligand-independent wnt signaling by the clathrin endocytic pathway. Dev. Cell 2018, 44, 566-581, 568. [CrossRef] [PubMed]

165. McGough, I.J.; Vincent, J.P. Apc moonlights to prevent wnt signalosome assembly. Dev. Cell 2018, 44, 535-537. [CrossRef] [PubMed]

166. Feng, Y.; Li, X.; Ray, L.; Song, H.; Qu, J.; Lin, S.; Lin, X. The drosophila tankyrase regulates wg signaling depending on the concentration of daxin. Cell. Signal. 2014, 26, 1717-1724. [CrossRef] [PubMed]

167. Chiang, Y.J.; Hsiao, S.J.; Yver, D.; Cushman, S.W.; Tessarollo, L.; Smith, S.; Hodes, R.J. Tankyrase 1 and tankyrase 2 are essential but redundant for mouse embryonic development. PLoS ONE 2008, 3, e2639. [CrossRef] [PubMed]

168. Adachi, S.; Jigami, T.; Yasui, T.; Nakano, T.; Ohwada, S.; Omori, Y.; Sugano, S.; Ohkawara, B.; Shibuya, H.; Nakamura, T.; et al. Role of a bcl9-related beta-catenin-binding protein, b91, in tumorigenesis induced by aberrant activation of wnt signaling. Cancer Res. 2004, 64, 8496-8501. [CrossRef] [PubMed]

169. Brembeck, F.H.; Wiese, M.; Zatula, N.; Grigoryan, T.; Dai, Y.; Fritzmann, J.; Birchmeier, W. Bcl9-2 promotes early stages of intestinal tumor progression. Gastroenterology 2011, 141, 1359-1370, 1370.e1351-1353. [CrossRef] [PubMed]

170. de la Roche, M.; Worm, J.; Bienz, M. The function of bcl9 in wnt/beta-catenin signaling and colorectal cancer cells. BMC Cancer 2008, 8, 199. [CrossRef] [PubMed]

171. Deka, J.; Wiedemann, N.; Anderle, P.; Murphy-Seiler, F.; Bultinck, J.; Eyckerman, S.; Stehle, J.C.; Andre, S.; Vilain, N.; Zilian, O.; et al. Bcl9/bcl91 are critical for wnt-mediated regulation of stem cell traits in colon epithelium and adenocarcinomas. Cancer Res. 2010, 70, 6619-6628. [CrossRef] [PubMed]

172. Li, B.; Rheaume, C.; Teng, A.; Bilanchone, V.; Munguia, J.E.; Hu, M.; Jessen, S.; Piccolo, S.; Waterman, M.L.; Dai, X. Developmental phenotypes and reduced wnt signaling in mice deficient for pygopus 2. Genesis 2007, 45, 318-325. [CrossRef] [PubMed]

173. Mani, M.; Carrasco, D.E.; Zhang, Y.; Takada, K.; Gatt, M.E.; Dutta-Simmons, J.; Ikeda, H.; Diaz-Griffero, F.; Pena-Cruz, V.; Bertagnolli, M.; et al. Bcl9 promotes tumor progression by conferring enhanced proliferative, metastatic, and angiogenic properties to cancer cells. Cancer Res. 2009, 69, 7577-7586. [CrossRef] [PubMed]

174. Moor, A.E.; Anderle, P.; Cantu, C.; Rodriguez, P.; Wiedemann, N.; Baruthio, F.; Deka, J.; Andre, S.; Valenta, T.; Moor, M.B.; et al. Bcl9/91-beta-catenin signaling is associated with poor outcome in colorectal cancer. EBioMedicine 2015, 2, 1932-1943. [CrossRef] [PubMed]

175. Takada, K.; Zhu, D.; Bird, G.H.; Sukhdeo, K.; Zhao, J.J.; Mani, M.; Lemieux, M.; Carrasco, D.E.; Ryan, J.; Horst, D.; et al. Targeted disruption of the bcl9/beta-catenin complex inhibits oncogenic wnt signaling. Sci. Transl. Med. 2012, 4, 148ra117. [CrossRef] [PubMed]

176. Thompson, B.; Townsley, F.; Rosin-Arbesfeld, R.; Musisi, H.; Bienz, M. A new nuclear component of the wnt signalling pathway. Nat. Cell Biol. 2002, 4, 367-373. [CrossRef] [PubMed]

177. Benchabane, H.; Xin, N.; Tian, A.; Hafler, B.P.; Nguyen, K.; Ahmed, A.; Ahmed, Y. Jerky/earthbound facilitates cell-specific wnt/wingless signalling by modulating beta-catenin-tcf activity. EMBO J. 2011, 30, 1444-1458. [CrossRef] [PubMed]

178. Xin, N.; Benchabane, H.; Tian, A.; Nguyen, K.; Klofas, L.; Ahmed, Y. Erect wing facilitates context-dependent wnt/wingless signaling by recruiting the cell-specific armadillo-tcf adaptor earthbound to chromatin. Development 2011, 138, 4955-4967. [CrossRef] [PubMed] 
179. Donovan, G.P.; Harden, C.; Gal, J.; Ho, L.; Sibille, E.; Trifiletti, R.; Gudas, L.J.; Toth, M. Sensitivity to jerky gene dosage underlies epileptic seizures in mice. J. Neurosci. 1997, 17, 4562-4569. [PubMed]

180. Liu, W.; Seto, J.; Donovan, G.; Toth, M. Jerky, a protein deficient in a mouse epilepsy model, is associated with translationally inactive mrna in neurons. J. Neurosci. 2002, 22, 176-182. [PubMed]

181. Moore, T.; Hecquet, S.; McLellann, A.; Ville, D.; Grid, D.; Picard, F.; Moulard, B.; Asherson, P.; Makoff, A.J.; McCormick, D.; et al. Polymorphism analysis of jrk/jh8, the human homologue of mouse jerky, and description of a rare mutation in a case of cae evolving to jme. Epilepsy Res. 2001, 46, 157-167. [CrossRef]

182. Morita, R.; Miyazaki, E.; Fong, C.Y.; Chen, X.N.; Korenberg, J.R.; Delgado-Escueta, A.V.; Yamakawa, K. Jh8, a gene highly homologous to the mouse jerky gene, maps to the region for childhood absence epilepsy on 8q24. Biochem. Biophys. Res. Commun. 1998, 248, 307-314. [CrossRef] [PubMed]

183. Toth, M.; Grimsby, J.; Buzsaki, G.; Donovan, G.P. Epileptic seizures caused by inactivation of a novel gene, jerky, related to centromere binding protein-b in transgenic mice. Nat. Genet. 1995, 11, 71-75. [CrossRef] [PubMed]

184. Zara, F.; Bianchi, A.; Avanzini, G.; Di Donato, S.; Castellotti, B.; Patel, P.I.; Pandolfo, M. Mapping of genes predisposing to idiopathic generalized epilepsy. Hum. Mol. Genet. 1995, 4, 1201-1207. [CrossRef] [PubMed]

185. DeSimone, S.M.; White, K. The drosophila erect wing gene, which is important for both neuronal and muscle development, encodes a protein which is similar to the sea urchin p3a2 DNA binding protein. Mol. Cell. Biol. 1993, 13, 3641-3649. [CrossRef] [PubMed]

186. Fazio, I.K.; Bolger, T.A.; Gill, G. Conserved regions of the drosophila erect wing protein contribute both positively and negatively to transcriptional activity. J. Biol. Chem. 2001, 276, 18710-18716. [CrossRef] [PubMed]

187. Virbasius, C.A.; Virbasius, J.V.; Scarpulla, R.C. Nrf-1, an activator involved in nuclear-mitochondrial interactions, utilizes a new DNA-binding domain conserved in a family of developmental regulators. Genes Dev. 1993, 7, 2431-2445. [CrossRef] [PubMed]

188. Major, M.B.; Roberts, B.S.; Berndt, J.D.; Marine, S.; Anastas, J.; Chung, N.; Ferrer, M.; Yi, X.; Stoick-Cooper, C.L.; von Haller, P.D.; et al. New regulators of wnt/beta-catenin signaling revealed by integrative molecular screening. Sci. Signal. 2008, 1, ra12. [CrossRef] [PubMed]

189. Pangon, L.; Ng, I.; Giry-Laterriere, M.; Currey, N.; Morgan, A.; Benthani, F.; Tran, P.N.; Al-Sohaily, S.; Segelov, E.; Parker, B.L.; et al. Jrk is a positive regulator of beta-catenin transcriptional activity commonly overexpressed in colon, breast and ovarian cancer. Oncogene 2016, 35, 2834-2841. [CrossRef] [PubMed]

190. Guo, Z.; Lucchetta, E.; Rafel, N.; Ohlstein, B. Maintenance of the adult drosophila intestine: All roads lead to homeostasis. Curr. Opin. Genet. Dev. 2016, 40, 81-86. [CrossRef] [PubMed]

191. Biteau, B.; Hochmuth, C.E.; Jasper, H. Jnk activity in somatic stem cells causes loss of tissue homeostasis in the aging drosophila gut. Cell Stem Cell 2008, 3, 442-455. [CrossRef] [PubMed] 